Scientific Journal Warsaw University of Life Sciences - SGGW

Problems of World Agriculture volume 17 (XXXII), number 4, 2017: 41-51

DOI: 10.22630/PRS.2017.17.4.80

\author{
Nadiya Davydenko ${ }^{1}$, Natalia Wasilewska ${ }^{2}$ \\ ${ }^{1}$ National University of Life and Environmental Sciences of Ukraine \\ 2 Jan Kochanowski University
}

\title{
Paradigm of Financial Provision of the Agricultural Land Restoration in Ukraine
}

\begin{abstract}
The purpose of the research was to determine the system of measures aimed at financial provision of restoration and improvement of the fertility of the agricultural lands, which are an important part of the state strategy for the development of the Ukrainian economy agrarian sector. Characteristics of land use in European countries and Ukraine were presented. The sources of financial provision of agricultural land restoration were analyzed. The measures aimed at successful restoration of fixed assets of agrarian enterprises, in particular land resources are proposed.
\end{abstract}

Key words: financial provision of agricultural land restoration, state strategy, agrarian sector, agrarian enterprises, restoration of land resources, financing programs, preferential loans

JEL Classification: Q15

\section{Introduction}

The main problem of the development and reform of land relations in Ukraine is the continued deterioration of living conditions in rural areas. Life in the village is becoming less attractive; the number of peasants interested in agricultural activities is decreasing; there is a change in the age structure of the village due to the population aging; the processes of migration of the rural population, including economically active, in search of better living conditions, etc. is expanded. All this leads to the rapid degradation of the villages and their disappearance from the map of Ukraine (Hvesyk et al., 2013).

After all, according to the State Statistics Service of Ukraine, during 2013-2016 800 Ukrainian villages disappeared from the map of our country; 9,232 villages have no business entities; in 4,097 villages there were no registered newborns during this period, and in more than 3,500 villages there are no children under the age of 5 .

In addition, the current ecological situation in Ukraine can be characterized as a crisis. Every year, according to the State Statistics Service of Ukraine, the air, water and land resources are contaminated with about 11 million tons of dangerous pollutants, of which $57 \%$ are harmful emissions into atmosphere, $40 \%$ - in surface water bodies, $3 \%$ - hazardous waste, polluting land resources.

In particular, during 2016, 3.1 million tons of pollutants and 150 million tons of carbon dioxide were released into the atmosphere. In the total number of harmful substances, emissions of sulfur dioxide and nitrogen oxide (which belongs to greenhouse

1 professor, National University of Life and Environmental Sciences of Ukraine, School of Economics, Department of Finance str. Heroiv Oborony, 10,03-041 Kyiv, Ukraine, e-mail: davidenk@ukr.net

2 doctor habilitated, professor of the UJK, Jan Kochanowski University, Piotrków Trybunalski Campus, School of Social Sciences, Department of Management, str. Gieysztora, 2/63, 02-999 Warszawa, Poland, e-mail: n.wasilewska@unipt.pl 
gases) are respectively $1,076.4$ thousand tons and 240.2 thousand tons. The size of environmental damage from production activities (losses of land, water and forest resources, pollution of the environment, etc.) in Ukraine, according to experts, exceeds UAH 50 billion each year.

The issue of financial provision, its availability and adequacy are one of the key tasks that can successfully solve the issues of conservation, improvement of agricultural lands, and thus the revival of Ukrainian villages.

Thus, the purpose of the research is to determine the system of measures aimed at financial provision for the restoration of land resources, which is an important part of the state strategy for the development of the Ukrainian economy agrarian sector.

The land in agriculture is spatially limited and is not artificially restored. Therefore, the prerequisite for expanded restoration in agriculture is the rational use of land and the implementation of measures for its restoration by preserving its fertility and environmental suitability.

In recent years one can observe how the rhetoric of specialists dealing with land valuation changes. If several years ago, on the pages of the leading editions, it was possible to read about unique Ukrainian black earths, that they were the best, and that a quarter of the world's black earths fell to Ukraine, then today there are growing questions about the thoughtless cultivation of Ukrainian lands. So, as of 2017 , more than $70 \%$ of Ukraine's land is occupied by agricultural lands. In the context of modern challenges, the primary task is to restore them.

Restoration of lands implies preserving and improving their fertility and environmental suitability. In order to maintain and improve the earth's fertility, the necessary financial provision is required.

The mechanism of financial provision for land restoration is rather complicated and insufficiently investigated. In the first place it is advisable to determine the methods and possible sources of financial support for the land restoration.

Depending on the strategy of financial policy and the state of the economy, financial regulation tools can exercise their influence in the form of constraints or incentives. It is worthwhile to distinguish the main forms (incentives, restrictions) and instruments (taxes, lending, price regulation, budget financing and investment) of financial regulation of the state economic development. It should also be noted that the choice of financial instruments and the degree of their influence should be laid incentive. In this case the financial regulation can play a significant role in ensuring economic development (Zelensky, 2016).

Thus, T.V. Mayorova distinguishes the following methods of financing: self-financing, corporatization, lending, budget financing, financing through free and charitable contributions, mixed funding (Mayorova, 2009).

I. Blank distinguishes the following methods of financial provision: self-financing; corporatization; loan financing; leasing; mixed funding (Blank, 2012).

But nowadays the direction of investment in the agro-industrial complex of Ukraine is accompanied by a number of obstacles. The main factors that negatively affect the investment climate and predetermine the high risk of investing in agribusiness are the overly prolonged and inconsistent character of market reforming of the economy, legal, economic and political instability, imperfect financial and credit and tax system, low level of market infrastructure development, lack of land market, etc. (Zelensky, 2016).

To date, it can be argued that the existing mechanisms for financing the agrarian sector of the Ukrainian economy, in particular mechanisms aimed at the restoration of land resources, 
need to be improved. In addition, there is an urgent need to develop a new system of measures adapted to the economic, social and political conditions in which the agrarian sector of the Ukrainian economy operates. It is this system of measures that should be the basis for a strategy aimed at financially supporting the restoration of agricultural lands.

\section{Stages of the research and methods}

The research involves the implementation of three stages.

The first stage involves an analysis of the current situation in Ukraine regarding mechanisms for financing the agrarian sector of the Ukrainian economy, in particular mechanisms aimed at the restoration of land resources.

Under the first stage of the study, method of analysis was used to study methodological approaches, concepts and proposals concerning financing mechanisms for the agrarian sector of the Ukrainian economy. The analytic and the systemic approaches were used for the analysis of legislative acts and other normative documents regulating relations in the area of land relations and state financial support of the agroindustrial complex in Ukraine.

The second stage involves: an analysis of the financial support under the state (budget) programs aimed at the development of the agroindustrial sector in Ukraine during the past 4 years; identification of the factors that restrain the restoration of land resources; as well as an assessment of the agrarian enterprises' ability to self-finance the restoration of fixed assets.

Under the research second stage, the following methods of scientific study have been applied: historical, analytical and logical methods - in the analysis process of agrarian enterprises' financial results; effectiveness evaluation of the state financial support to the agroindustrial sector; as well as analysis of the land resources' structure and information related to exploitation of land resources.

The third stage of the study involves using the abstract and logical methods to prepare the complex of measures for increase efficiency of the financial support strategy for restoration of land resources.

\section{The research results}

The results of the conducted research determined that the possible sources of funding for all methods of financial support for the restoration of agricultural lands are as follows: a) profit; b) depreciation deductions; c) funds from the sale of used fixed assets; d) funds from the issue of shares; e) bank loan; f) forfeiting; g) mortgage loan; h) public credit; i) foreign credit; j) bond loans; k) agricultural receipts; l) operating and financial leasing; m) investment tax credit; n) subsidies, grants, subventions.

The use of funds from these sources will attract and effectively use funds for financial provision for the land restoration, taking into account the state of material and technical fixed assets, considering sources and conditions for obtaining funds, organizational forms of activities of enterprises, forms of ownership of sources.

Most of the possible sources of financial provision for the restoration of fixed assets in practice are virtually not used in Ukraine, especially in agrarian enterprises. 
The basis for self-financing the restoration of fixed assets of business entities is net income and depreciation deductions. We will analyze and try to evaluate the possibility of agrarian enterprises to self-finance the restoration of fixed assets (Table 1).

Table 1. Own Financial Resources of Agrarian Enterprises In Ukraine, 2010-2016 years

\begin{tabular}{l|rrrrrrr}
\hline \multicolumn{1}{c|}{ Ratios/Years } & 2010 & 2011 & 2012 & 2013 & 2014 & 2015 & 2016 \\
\hline Net profit, billion UAH & 17.3 & 25.3 & 26.7 & 15.1 & 21.7 & 103.1 & 90.7 \\
Amortization deductions, billion UAH & 4.0 & 4.9 & 6.5 & 7.0 & 8.3 & 10.2 & 11.0 \\
$\begin{array}{l}\text { Total net profit and depreciation deductions, } \\
\text { billion UAH }\end{array}$ & 21.3 & 30.2 & 33.2 & 22.1 & 30.1 & 113.3 & 101.7 \\
\hline
\end{tabular}

Source: prepared on the basis of statistical data (Statistical Yearbook of Ukraine "Agriculture in Ukraine for 2016", 2017).

Data analysis in Table 1 allows us to conclude as follows. Positive is the growth of the amount of depreciation deductions from UAH 4 billion in 2010 up to UAH 11 billion in 2016, i.e. in 2.75 times. The increase in the amount of depreciation deductions increases the ability of agrarian enterprises to provide independent financial provision for the restoration of agricultural lands.

Positive is the growth of the absolute amount of net profit of agrarian enterprises from UAH 17.3 billion in 2010 to UAH 90.7 billion in 2016 . However, there is a fluctuation in the amount of net profit of agrarian enterprises in certain years. There is no doubt that fluctuations in the net profit of agrarian enterprises are due to the specifics of agrarian production, its dependence on natural conditions, their changes in some years, fluctuations of world prices for agricultural products and increased costs of its production. Fluctuations in the volume of net profit depends on the organizational forms of activity, the size of the enterprise. In 20102012, the growth of net profit of agrarian enterprises of Ukraine grew by 55\%. But in 2013 there is a significant decrease in net profit - in 1.8 times. In 2016, compared to 2010, net profit increased by $524.28 \%$. However, the profit of agrarian enterprises cannot be considered as a fairly stable source of financial support for the restoration of agricultural lands. Indeed, under such an economic situation, which is characterized by extremely high inflation (over $230 \%$ from 2010 to 2016), a significant part of the profits of agrarian enterprises is 'eaten'.

Own financial resources in agrarian enterprises are not enough to allocate them to the restoration of agricultural land; therefore, external sources of financial provision are important.

The rural development support programs and namely, expenditures for the development of agricultural servicing cooperatives, farms, agricultural advisory services provide insignificant and volatile funding (Ostaszko et al., 2010).

However, if we analyze the use of land by types of economic entities in 2016, then a significant proportion falls on agricultural households $-36.76 \%$ (Table 2 ).

Attention is also drawn to the destructives of the budgetary financial support of the state. First of all, it concerns the financing of agricultural lands, because in the EU, financial support for agricultural development is not directly related to the efficiency of cultivating products (Shchuryk, 2016). Thus, in the EU, farmers receive direct per-hectare payments that are not related to production efficiency (this support ranges from USD 500-600 in the EU countries to USD 200-300 in the USA and Canada), and only a few countries apply the practice of payments related to the productivity of agricultural activity (Ostaszko et al., 2010). 
State support can be direct and indirect. In Ukraine, direct state support for agriculture remains low compared to EU countries. According to Annex 2 to the Agreement on Agriculture of the WTO, 1994, all measures for state support to agriculture are conditionally divided into three groups, or distributed in colored boxes: "green", "blue" and "yellow".

Table 2. Use of Agricultural Lands by Types of Economic Entities (as of 2016)

\begin{tabular}{|c|c|c|c|c|c|}
\hline \multirow[b]{2}{*}{ Business entities } & \multirow{2}{*}{$\begin{array}{c}\text { Number of } \\
\text { thousand } \\
\text { units }\end{array}$} & \multicolumn{2}{|c|}{ Agricultural lands } & \multicolumn{2}{|c|}{ Ploughlands } \\
\hline & & $\begin{array}{l}\text { thousand } \\
\text { units }\end{array}$ & $\begin{array}{c}\text { specific } \\
\text { weight, } \%\end{array}$ & thousand units & $\begin{array}{c}\text { specific } \\
\text { weight, } \%\end{array}$ \\
\hline Agricultural households & $13.0^{*}$ & 15706.4 & 36.8 & 11655.8 & 35.8 \\
\hline Agricultural enterprises & & 20746.9 & 48.5 & 19476.1 & 59.9 \\
\hline - private & 3.6 & 19809.9 & 46.4 & 18702.2 & 57.5 \\
\hline - $\quad$ state & 0.2 & 937 & 2.1 & 773.9 & 2.4 \\
\hline $\begin{array}{l}\text { Enterprises of other business } \\
\text { patterns }\end{array}$ & 33.2 & & 14.7 & 1409.4 & 4.3 \\
\hline Total & $45.4^{* *}$ & 42726.4 & 100.0 & 32541.3 & 100.0 \\
\hline
\end{tabular}

* number of rural population, million people

** the total amount of economic entities is indicated excluding households in rural areas

Source: prepared on the basis of statistical data (Statistical Yearbook of Ukraine "Agriculture in Ukraine for 2016", 2017)

The financial support of agricultural producers in Ukraine (mostly indirect - at the expense of special regime) barely reaches 40 euros per hectare. Currently, almost $80 \%$ of financial assistance from the state budget is accounted for big companies or agroholdings. At the same time, as evidenced by the experience of the EU countries, the USA and Canada, the medium and small agricultural enterprises represented by the absolute majority of farmers are prevailing in the agriculture. Characteristics of land use in European countries and Ukraine are presented in Table 3.

Nowadays the state strategy of enhancement of management in the field of use and protection of lands of agricultural in Ukraine is not effective. Such conclusion is confirmed by the analysis of the indicators mentioned in the Table 3.

Table 3. Comparative characteristics of land use in European countries and Ukraine

\begin{tabular}{|c|c|c|c|}
\hline Characteristics & Ukraine & European countries & Countries of EU \\
\hline Land area, mln hectares & 60.4 & 1015.6 & 437.4 \\
\hline Chernozem area, mln hectares & 28.0 & 84.0 & 18.0 \\
\hline Area of agricultural land, mln hectares & 42.7 & 474.8 & 177.7 \\
\hline Area of arable land, mln hectares & 32.5 & 277.8 & 115.7 \\
\hline The share of leased agricultural land, $\%$ & 97.0 & 62.0 & 53.0 \\
\hline Area of organic agricultural land, mln hectares & 0.3 & 11.6 & 5.3 \\
\hline Area of irrigated land, mln hectares & 0.5 & 20.8 & 11.1 \\
\hline Investment, USD thousands $/ 1$ hectare & 1.0 & 4.0 & 5.5 \\
\hline Grain exports, mln tons & 34.8 & 130.0 & 38.5 \\
\hline Area of agricultural land, hectares / person & 0.7 & 0.6 & 0.4 \\
\hline $\begin{array}{l}\text { Price per one hectare of agricultural land, USD } \\
\text { thousand }\end{array}$ & & 3.7 & 7.2 \\
\hline
\end{tabular}

Source: Strategy to improvement of land management mechanism in Ukraine, June 7, 2017. 
Thus, the results of the analysis of the European countries legislation show that each of them (countries) have various restrictions in the area of using and protection of agricultural lands. Restrictions related to the size of land plots are characteristic of countries with economies in transition and countries with limited land resources. As a rule, such restrictions are established at the municipal or regional level, in particular: Hungary - no more than 300 hectares (for individuals and legal entities); Romania - no more than 200 hectares (for individuals and legal entities); Denmark - no more than 30 hectares (for persons who have professional education and farmer experience) (Strategy to improvement of land management mechanism in Ukraine, June 7, 2017).

Inefficient use of land resources as well as depletion of soil fertility in Ukraine are explained by an extremely high proportion of land cultivation, absence of appropriate restrictions on land use, as well as the lack of clear requirements for land users.

The expenditures financing by the Ministry of Agrarian Policy and Food of Ukraine at the expense of the State Budget Special Fund is presented in Table 4. As we see, the total amount of financing of the agroindustrial complex at the expense of the State Budget Special Fund for the last two years has decreased by 294.6 million UAH. So, since 2015, implementation of the budget program of financial support of the livestock sector has been suspended.

Lending is very significant in financial support for the restoration of agricultural lands, due to lack of own funds. At the same time, obtaining loans to agricultural enterprises of Ukraine remains problematic. The lending to agrarian enterprises is negatively impacted by: growth of interest rates on loans (increased from $14.9 \%$ in 2010 to $16.1 \%$ as of July 2017 , with a decrease in the profitability of fixed assets of agrarian enterprises from $18.4 \%$ in 2010 to $10.8 \%$ in 2017); lack of a specialized agricultural bank (only 8 banks offer individual loan repayment schedules, taking into account the peculiarities of agrarian enterprises); reduction of state financial support of agrarian enterprises through the loans cheapening mechanism (from UAH 50 billion in 2000 to planned UAH 300 million in 2017); high requirements of banks in lending agrarian enterprises to mortgage property and its insufficiency.

Land resources are the main productive force in agrarian enterprises, the restoration of which largely depends on their financial support. Insufficient amounts of financial resources restrict the use of such a form of restoration of land, as reclamation. Land reclamation is a complex of works aimed at restoring productivity and economic value of disturbed lands, improving environmental conditions (Danylyshyn, Hvesyk, Holian, 2009). Land reclamation requires significant financial resources available for agribusinesses (agricultural holdings) and not available for small and medium-sized agribusinesses. However, even if there is sufficient financial resources, agricultural holdings do not provide full land restoration. The main reason, in our opinion, is irresponsible attitude to the land, because owners consider the land only as a commodity. The irresponsible activity of a modern human generates degradation phenomena in many spheres of social life, and agriculture isn't an exception.

Therefore, at the state level, it is necessary to oblige all economic entities, regardless of the organizational and legal form, to financially ensure the restoration of the land cultivated by them.

At the end of 2016 there were 47,697 agricultural enterprises in Ukraine, which owned and used 19.8 million hectares of agricultural lands; 18.9 million hectares of ploughland (Statistical Yearbook of Ukraine "Agriculture in Ukraine for 2016", 2017). 
Table 4. Expenditure financing by the Ministry of Agrarian Policy and Food of Ukraine at the expense of the State Budget Special Fund

\begin{tabular}{|c|c|c|c|c|c|}
\hline Expenditures & 2014 & 2015 & 2016 & 2017 & $\begin{array}{c}(+;-) \\
2017 / 2014\end{array}$ \\
\hline $\begin{array}{l}\text { Apparatus of the Ministry of Agrarian Policy and } \\
\text { Food of Ukraine }\end{array}$ & 1941.5 & 200.9 & 180.8 & 1646.9 & -294.6 \\
\hline $\begin{array}{l}\text { Research, applied scientific and technical } \\
\text { developments, works on state target programs and } \\
\text { government orders in the field of development of } \\
\text { agroindustrial complex, research and experimental } \\
\text { development in the field of agroindustrial complex }\end{array}$ & 33.5 & 35.3 & 37.2 & 48.5 & 15.0 \\
\hline $\begin{array}{l}\text { Qualification improvement of agroindustrial complex } \\
\text { specialists }\end{array}$ & 6.7 & 6.6 & 6.6 & 8.5 & 1.8 \\
\hline $\begin{array}{l}\text { Training of personnel for agroindustrial complex by } \\
\text { higher educational institutions of the I-IV levels of } \\
\text { accreditation }\end{array}$ & 808.4 & - & - & - & -808.4 \\
\hline $\begin{array}{l}\text { Financial support of events in the agroindustrial } \\
\text { complex }\end{array}$ & 5.0 & 5.0 & 5.0 & - & -5.0 \\
\hline $\begin{array}{l}\text { The expenditures of the Agrarian Fund related to the } \\
\text { complex of measures for storage, transportation, } \\
\text { processing and export of objects of state price } \\
\text { regulation of the state intervention fund }\end{array}$ & 100.0 & 100.01 & 100.0 & 51.4 & -48.6 \\
\hline $\begin{array}{l}\text { Increase of the authorized capital of NJSC } \\
\text { Ukragroleasing for the purchase of technical means } \\
\text { for agroindustrial complex with their subsequent } \\
\text { transfer under financial leasing conditions }\end{array}$ & - & 54.0 & - & - & $\mathrm{x}$ \\
\hline $\begin{array}{l}\text { Organization and regulation of activity of institutions } \\
\text { in the system of agroindustrial complex and } \\
\text { provision of activities of the Agrarian Fund }\end{array}$ & - & - & 32.0 & 33.5 & 33.5 \\
\hline $\begin{array}{l}\text { State support for the development of hop-growing, } \\
\text { the laying of young gardens, vineyards and berries }\end{array}$ & 100.0 & - & - & - & -100.0 \\
\hline State support to the livestock sector & 888.0 & - & - & - & -888.0 \\
\hline Financial support of agricultural producers & - & - & - & 1500.0 & 1500.0 \\
\hline
\end{tabular}

Source: prepared on the basis of Law of Ukraine "On the State Budget of Ukraine for 2017".

On the other hand, in Ukraine there continues to be an extremely high proportion of land cultivation (Fig. 1). In Ukraine, more than $92 \%$ of the territory is involved for economic use. Extremely high is the level of cultivation of the territory and is more than $54 \%$ (in the developed countries of Europe it does not exceed 35\%). The actual forest area of Ukraine is only $16 \%$, which is not enough to ensure environmental equilibrium (the average indicator of European countries - 25-30\%) (Strategy to improvement of land management mechanism in Ukraine, June 7, 2017).

Such a high level of land cultivation leads to a disturbance of the ecologically balanced ratio of land resources, namely agricultural lands, forests and reservoirs. In turn, this negatively affects the stability of agro-landscapes and causes a significant technological burden on the environmental sphere.

Much of the low-yielding land is part of the arable land: almost every 5th hectare of arable land falls on low-yielding land. With the use of land, there is a tendency to maximize the area of agricultural lands, especially arable, which leads to the intensity of degradation 
processes. At the same time, land seizures for non-agricultural use often occur at the expense of suitable ones. A significant drawback is the unsystematic monitoring of quality soil parameters and anthropogenic loading carried out by economic activity, which makes it practically impossible to analyze the state of assimilation potential of the territory. Its systematic conduct will allow timely identifying any deviations from the established norms and assessing the possibility of using the territories under ecologically safe production. This confirms the necessity of urgent development and introduction of measures for optimization of land use, prevention of degradation processes, increase of agriculture productivity (Lisova, 2015).
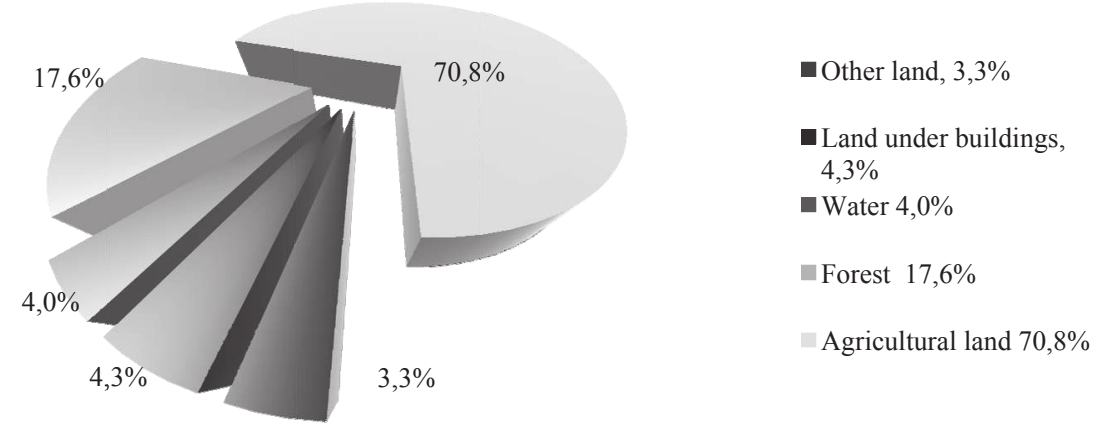

Fig. 1. Land area of Ukraine at 1 January 2016

Source: prepared on the basis of Strategy to improvement of land management mechanism in Ukraine, June 7, 2017.

Agrarian enterprises of Ukraine do not fully utilize the competitive advantage of natural potential of land in the cultivation of agricultural products. More than $90 \%$ of land resources, used by agrarian enterprises in Ukraine, are used on lease terms. Therefore, agrarian enterprises are aimed at increasing the volumes of crops and maximizing profits, violating the optimal structure of the acreage of agricultural crops, oversaturating land with herbicides, mineral fertilizers and other chemicals, which causes accelerated depletion of the soil and deterioration of its qualitative properties. That is, there is no real landowner who would be interested in preserving and restoring its natural potential. As of 01.01.2015, 4.8 million lease agreements for land shares with a total area of more than 17 million hectares or $64.4 \%$ of the total area of shared if agricultural lands were concluded. Therefore, agrarian enterprises conduct their economic activity mainly on leased land, which accounts for over $93 \%$ of their total land use (Lisova, 2015). The situation over the past two years has not changed.

The inefficiency state policy in the field of land use (high proportion of land cultivation, lack of effective organizational and financial mechanisms to prevent soil fertility decline) has a negative impact on the agrarian sector development, in particular on agricultural production and productivity (Fig. 2).

The mentioned above proves that nowadays restoration and improvement of the fertility of the agricultural lands are an extremely significant problem for Ukraine. There are the following conclusions made on the basis of the research results:

1. One of the features of land is its ability to natural self-restoration. At the same time, centuries-old practice knows two variants of natural preservation of the earth:

- $\quad$ scientifically grounded application of crop rotation;

- full rest of the land from crops (use of complete fallows). 
Restoration of land in a natural way does not require additional, substantial costs, and hence financial resources. But the implementation of this direction of (natural) land restoration requires a clear (effective) administrative control system which should be combined with the simultaneous use of economic and financial levers.

2. The use of land as a means of production in agriculture requires taking into account the biological laws of the natural development, conservation and restoration of natural resources. The imperfection of technological processes of modern production exacerbates environmental problems in agrarian enterprises. Therefore, in the process of expanded restoration implies the increase of costs for restoring and preserving natural resources, in particular, restorating soil fertility.

3. Reduced land quality occurs in agriculture due to excessive saturation of land with mineral fertilizers, pesticides, herbicides. Their intensive use by agrarian enterprises is due to: failure to crop rotation; violation of the optimal structure of sown areas of agricultural crops; orientation on the production of certain crops that have a high level of profitability; specialization of large agrarian enterprises on growing of export-oriented agricultural crops of the grain group. The saturation of land with various chemicals is accompanied by a decrease in the quality of agricultural products, the receipt of products harmful to the health of people and animals consuming such products.

4. It is advisable to exempt economic entities who give full rest to the land (exempt it from crops) from the taxation of these land (upon payment of a single tax).

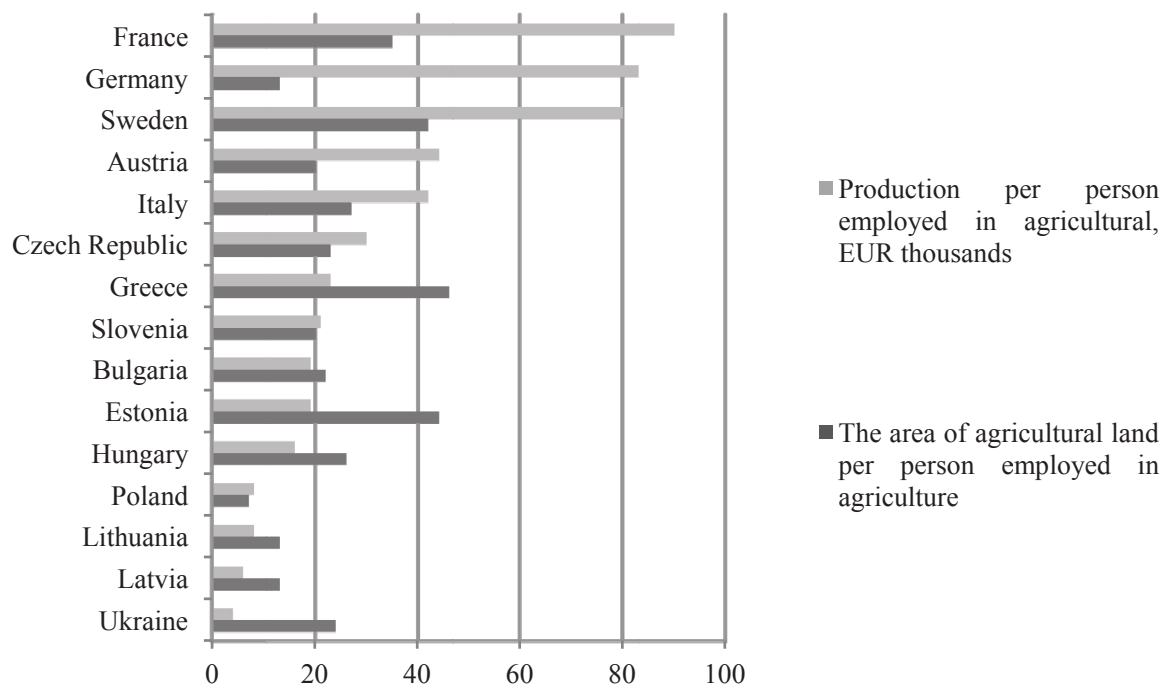

Fig. 2. Production and area of agricultural land per person employed in agriculture

Source: Strategy to improvement of land management mechanism in Ukraine, June 7, 2017.

The land share used for complete fallows from the total area of land used by the business entity must be scientifically justified for individual regions, natural zones, depending on the specialization in the cultivation of individual crops. Some economic sanctions (penalties) can be applied to the economic entities that do not adhere to the norms for using the land under complete fallow. 
In the case of business entities, which adhere to or do not adhere to the recommended crop rotation, it is possible to establish certain privileges or apply penalties.

\section{Conclusions}

The agrarian sector is a strategically important sector of the Ukrainian economy. The strategy of financial support for restoration of land at the macro level should be consistent with the overall national strategy for agricultural development. Despite the significant problems associated with land degradation due to non-compliance with crop rotation, the uncontrolled use of chemical fertilizers and the lack of organic fertilizers, Ukraine still has potential for successful land restoration. For this, at the state level, it is necessary to carry out the following measures:

- to develop a strategy of financial provision for restoration of land at the macro level;

- to contribute to ensuring a stable economic situation in the country in order to attract investments in the agricultural sector, and, in particular, for land restoration;

- introduction of permanent monitoring of the use of funds received from the state for land restoration (for this purpose, it is expedient to improve the financial reporting on the use of state financial support funds);

- exempt from taxation the part of the land to which the natural restoration applies (complete fallows);

- to create the legal and economic preconditions for restoration of the fertility of the agricultural lands by improvement of legislation basis for related to land management. For example, the State Budget of Ukraine provides for the allocation of funds for the implementation of environmental protection measures at the expense of funds received under the article "environmental tax", where $53 \%$ of the total amount received from paying this tax should come to the special fund of the State Budget of Ukraine. At the same time, in the budget, in particular in this part, there is no specification of environmental measures for which these funds are allocated.

Moreover, during the past 4 years, capital investments and current expenditures on environmental protection measures have risen from 20.4 billion UAH in 2013 to 32.5 billion UAH in 2016. But just only 325 million UAH in 2013 and 420 million UAH in 2016 were aimed at protecting and rehabilitating the soil. It should be noted that such financing is inadequate and ineffective. Based on the results of conducted statistical surveys, the main source of financing for a complex of measures aimed at protecting the environment (capital investment) is the own funds of enterprises, and only about $2.8 \%$ of the total funding is financed from the State Budget of Ukraine. It is the same situation related to the current expenditure on environmental protection.

However, now it is difficult to say how many financial costs are required to implement an effective integrated program for agricultural land restoration. First of all, it is necessary to create such program as well as clearly define the system of measures within the framework of such program. Just in this case there will be possible to calculate the required financing.

Summarizing the results of the conducted research it was established that at the state level, the strategy aimed at financial support for the restoration of agricultural lands should be realized through: creation of the legal preconditions, implementation of special financing programs, granting of preferential loans, attracting foreign investments, preferential taxation conditions. 


\section{References}

Aquilina, D., Gardner, S., Goncalves, A., Hudson, T., Kjellberg, O., McGlynn, D., Strano, A., Toth, P., Vaivod, D. (2012). Rural development financial instruments: New opportunities to tackle the economic crisis, EU Rural Review, $\mathrm{N}^{\circ} 13$. Accessed from: http://enrd.ec.europa.eu/enrd-static/fms/pdf/69D9962A-A9D5-5298-0AB7C4B02470D0B5.pdf.

Blank, I. (2012). Fundamentals of Financial Management, Omega-L Publisher, Moscow.

Damarey, S. (2008). Finances Publiques: Finances de L'etat, Finances Locales, finances Sociales, Finances Europeennes. Gualino Publisher, Coll. Manuels.

Danylyshyn, B., Hvesyk, M., Holian, V. (2009). Environmental Economics, Condor Publisher, Kyiv.

Hvesyk, M., Ibatullin, Sh., Lysun, S., et al. (2013). Formation of natural resources management model in market conditions. Kyiv: SA IEPSR NAS of Ukraine Publisher, Kyiv.

Land legislation of Ukraine: collection of legal rights acts, Istyna Publisher, Kyiv.

Law of Ukraine "On Stimulation of Agricultural Development for the Period 2001-2004", January 18, 2001 No. 2238-III // http://zakon.rada.gov.ua/cgi-bin/laws/main.cgi.

Law of Ukraine "On the State Budget of Ukraine for 2017". http://zakon2.rada.gov.ua/laws/show/1801-19.

Lisova, T. (2015). Features of measures of legal protection and revitaization of agricultural lands. Scientific Bulletin, 34(2), 48-51.

Mayorova, T. (2009). Investing, TsUL Publisher, Kyiv.

Ostaszko, T., Mołdowan, L., Borodina, O., Yurshyshyn, V., Paskhaver, B., Prokopa, I., Shubravska, O. (2010) Agrarian sector: Time to fundamentally change benchmarks. Week mirror. Accessed from: http://dt.ua/ECONOMICS/agrarniy_sektor_chas_printsipovo_zminiti_orientiri_rozvitku-60696.html?print.

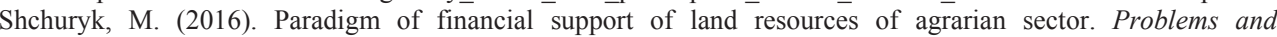
Perspectives of Economy and Management, 2, 279-288.

Statistical Yearbook of Ukraine. Agriculture in Ukraine for 2016. (2017). State Statistics Service of Ukraine Publisher, Kyiv.

Strategy to improvement of land management mechanism in Ukraine, June 7, 2017, No. 413. Accessed from: http://zakon2.rada.gov.ua/laws/show/413-2017-\%D0\%BF.

Wishlade, F., Michie, R. (2014). Financial instruments in 2014-20: learning from 2007-13 and adapting to the new environment. European Policies Research Centre, University of Strathclyde.

Zelensky, A. (2016). Financial Regulation of the Agrarian Sector of Ukraine's Economy. Manuscript, Kyiv. 